\title{
HUBUNGAN KARAKTERISTIK INDIVIDU DENGAN KEJADIAN PENYAKIT KUSTA (Studi Kasus di Wilayah Kerja Puskesmas Tanjung Kabupaten Sampang Tahun 2018)
}

Aning Hidayatun N, Nur Haidah, A.T Diana Nerawati

Abstrak

Jawa Timur merupakan provinsi yang memiliki kasus kusta baru paling banyak di Indonesia. Dilihat dari rata-rata prevalensi/10.000 penduduk kabupaten Sampang menduduki peringkat tertinggi penyakit kusta di Jawa Timur. Karakteristik individu dengan kusta yaitu jenis kelamin, umur, tingkat pendidikan, tingkat pengetahuan, personal hygiene dan status gizi diyakini berhubungan dengan kejadian kusta. Tujuan penelitian untuk mengetahui hubungan antara karakteristik individu dengan kejadian penyakit kusta di wilayah kerja Puskesmas Tanjung Kabupaten Sampang.

Penelitian ini merupakan penelitian observasional analitik dengan desain case control. Pengumpulan data dilakukan dengan wawancara. Populasi dalam penelitian ini sebanyak 28 orang dengan besar sampel sebanyak 26 orang kelompok kasus dan 26 orang kelompok kontrol. Data yang diperoleh dianalisis menggunakan uji Regresi Logistik.

Hasil analisis bivariat adanya hubungan antara karakteristik individu dengan kejadian penyakit kusta yaitu jenis kelamin ( $\rho$ value $=0,001)$ tingkat pendidikan $(\rho v a / u e=0,001)$ tingkat pengetahuan ( $\rho$ value $=0,012$ ) personal hygiene $(\rho v a / u e=0,006)$ status gizi ( $\rho$ value $=0,010)$. Sedangkan yang tidak berhubungan adalah umur ( $\rho$ value $=1,000)$. Hasil analisis multivariat yang bermakna ( $\rho$ value $<0,05)$ yaitu jenis kelamin $(\rho v a l u e=0,005)$, tingkat pendidikan ( $\rho$ value $=0,012$ ) dan personal hygiene $(\rho v a / u e=0,039$ ).

Kesimpulannya jenis kelamin, tingkat pendidikan, tingkat pengetahuan, personal hygiene dan status gizi berhubungan dengan kejadian penyakit kusta, sedangkan umur tidak ada hubungan dengan kejadian kusta. Variabel yang paling berpengaruh adalah jenis kelamin, tingkat pendidikan dan personal hygiene. Disarankan untuk membuat prioritas dalam meningkatkan penyuluhan kesehatan tentang pengendalian penyakit kusta. Bekerjasama dengan lintas program dan lintas sektor, serta meningkatkan motivasi masyarakat untuk hidup bersih dan sehat (PHBS).

Kata kunci : Kusta, karakteristik individu

\section{Pendahuluan}

Penyakit kusta atau lepra merupakan penyakit menular yang disebabkan oleh infeksi bakteri Mycobacterium leprae. Penyakit kusta ini dibagi dalam 2 tipe yaitu tipe Pausibasilar (PB) dan Multibasilar (MB). Kusta tipe PB adalah tipe kusta yang tidak menular, sedangkan kusta tipe MB adalah kusta yang menular. Penyakit ini dapat menyebabkan masalah yang kompleks, bukan hanya dari segi medis seperti cacat fisik tetapi juga sampai masalah sosial ekonomi, budaya, keamanan dan ketahanan nasional. Bila tidak ditangani dengan cermat, kusta dapat menyebabkan cacat dan keadaan ini menjadi penghalang bagi pasien kusta dalam menjalani kehidupan masyarakat untuk memenuhi kebutuhan sosial ekonominya (Widoyono, 2011).

Penyakit ini sendiri merupakan salah satu gambaran nyata kemiskinan di masyarakat Indonesia, karena 
kenyataannya sebagian besar penderita kusta berasal dari golongan ekonomi lemah. Adanya hubungan yang bermakna antara tingkat pengetahuan sebagai satu bagian dari perilaku dengan proses penularan dan penyembuhan pada penderita kusta. Seseorang yang berpengetahuan tinggi tentang kusta tentu akan menjauhkan dirinya dari sumber penularan serta faktor-faktornya yang mempengaruhinya (Manyullei $S$, Utama DA, Birawida AB, 2012).

Berdasarkan penelitian Wijayanti J (2017) menyatakan bahwa sebagian besar penderita kusta terdapat pada kategori umur produktif yaitu kisaran 1564 tahun mendapat prosentase sebesar $88,2 \%$. Jenis pekerjaan yang ditekuni penderita adalah sebagai buruh tani yang merupakan pekerjaan yang membutuhkan banyak energi yaitu sebesar 50\%. Jenis kelamin laki-laki lebih banyak menderita kusta dibanding perempuan yaitu sebanyak 64,7\%. Laki-laki biasanya kurang memperhatikan kebersihan diri dibandingkan perempuan, hal ini dibuktikan bahwa rata-rata responden laki-laki memiliki kebiasaan mandi $\leq 2$ kali sehari, karena kebiasaan mandi yang buruk tersebut dapat meningkatkan risiko tertular kusta. Tingkat pengetahuan pada penderita kusta paling banyak adalah pengetahuan rendah yaitu sebesar $55,90 \%$. Penderita dapat terinfeksi kusta dipengaruhi oleh pengetahuan yang dimilikinya karena tingkat pengetahuan akan mempengaruhi personal hygiene dari penderita tersebut. Jika pengetahuan yang baik maka personal hygienenya juga akan baik.

Personal hygiene sangat erat dengan kebersihan masyarakat dan saling mempengaruhi secara timbal balik. Makin banyak orang yang memperhatikan pemeliharaan dan peningkatan kesehatan dirinya, makin baik pula kesehatan masyarakatnya. Personal hygiene yang buruk merupakan cermin dari kondisi lingkungan dan perilaku individu yang tidak sehat (Namira N, 2014). Personal hygiene yang tidak baik akan mempermudah tubuh terserang berbagai penyakit, seperti penyakit kulit, penyakit mulut, penyakit saluran cerna atau bahkan dapat menghilangkan fungsi bagian tubuh tertentu, seperti halnya kulit dan penyakit infeksi.

Pada penularan infeksi penyakit kusta, diketahui bahwa faktor nutrisi memiliki peran yang penting. Jika seseorang berkontak langsung dengan penderita dan tidak memiliki konsumsi kalori dan protein yang cukup maka dia akan dengan mudah terserang Mycobacterium leprae (Rahfiludin, M.Z., Apoina, Distrika, 2005). Status gizi pada pasien kusta memiliki pengaruh nyata terhadap daya tahan tubuhnya. Interaksi antara infeksi termasuk penyakit kusta dan gizi di dalam tubuh seseorang dikemukakan sebagai suatu peristiwa sinergistik, selama terjadinya infeksi, status gizi akan menurun dan orang tersebut menjadi kurang resisten terhadap infeksi. Respon imun menjadi kurang efektif dan kuat ketika seseorang mengalami gizi kurang (Apriani, Rismayanti, Wahidudin, 2013).

Jawa Timur merupakan provinsi yang memiliki kasus baru paling banyak di Indonesia. Dari total kasus baru di Indonesia, Jawa Timur menyumbang kasus sebesar 23-35\%. Angka penemuan kasus baru pun sejak tahun 2000 belum 
pernah turun di bawah 5 per 100.000 penduduk. Hal tersebut mengindikasikan bahwa diperlukan sebuah upaya untuk menggambarkan kecenderungan angka penemuan kasus baru kusta dan faktor yang mempengaruhinya pada wilayah kabupaten/kota provinsi Jawa Timur. Berdasarkan data Dinas Kesehatan Provinsi Jawa Timur, penyakit kusta di Jawa Timur mencapai 4.058 orang atau memiliki prevalensi pada tahun 2016 masih 1.04 per 10.000 penduduk. Dilihat dari rata-rata prevalensi/10.000 penduduk kabupaten Sampang menduduki peringkat tertinggi penyakit kusta di Jawa Timur. Berdasarkan data dari Dinas Kesehatan Kabupaten Sampang penderita kusta tahun 2017 berjumlah 251 penderita.

Puskesmas Tanjung Kabupaten Sampang memiliki jumlah penderita yang terdaftar pada tahun 2017 sebanyak 28 orang, penyakit kusta bertipe PB dan bertipe MB. Berdasarkan data dari Dinas Kesehatan Kabupaten Sampang, Puskesmas Tanjung termasuk dalam 5 kategori tertinggi kasus kusta di Sampang pada tahun 2017. Orang yang berobat di puskesmas tersebut adalah orang yang tertular dari penderita kusta yang memiliki kontak langsung dengan penderita dalam waktu yang lama.

Tujuan dari penelitian ini adalah mengetahui hubungan antara karakteristik individu dengan kejadian penyakit kusta di Wilayah Kerja Puskesmas Tanjung Kabupaten Sampang Tahun 2018.

\section{Metode}

Jenis penelitian yang digunakan adalah penelitian observasinal analitik dengan desain case control adalah suatu penelitian analitik yang digunakan untuk menyelidiki orang-orang yang menderita penyakit atau efek (kasus) yang hendak diselidiki penyebabnya (faktor risiko) dibandingkan dengan orang-orang yang tidak menderita penyakit atau efek tersebut (kontrol) yang dilakukan secara retrospektif (Budiman, 2011).

Pengumpulan data dilakukan dengan wawancara. Populasi dalam penelitian ini sebanyak 28 orang dengan besar sampel sebanyak 26 orang kelompok kasus dan 26 orang kelompok kontrol.

Kasus adalah warga yang tercatat sebagai penderita di buku registrasi Kusta Puskesmas Tanjung Kabupaten Sampang mulai tahun 2017. Kontrol adalah warga yang tidak menderita kusta yang tinggal bertetangga dengan kelompok kasus dengan berbandingan 1:1.

Variabel Bebas pada penelitian ini adalah karakteristik individu meliputi jenis kelamin, umur, tingkat pendidikan, tingkat pegetahuan, personal hygiene dan status gizi. Sedangkan Variabel Terikat pada penelitian ini adalah kejadian penyakit kusta.

Uji yang digunakan dalam penelitian ini adalah uji Regresi Logistik dengan analisis univariat, bivariat dan multivariat.

\section{Hasil dan Pembahasan}

1. Distribusi Kejadian Penyakit Kusta di Wilayah Kerja Puskesmas Tanjung

Berdasarkan hasil wawancara dengan 52 responden, distribusi frekuensi karakteristik responden pada penelitian ini dapat dilihat pada Tabel 1. berikut :

Tabel 1. Distribusi Frekuensi Karakteristik Responden di Wilayah Kerja Puskesmas Tanjung Kabupaten Sampang Tahun 2018 


\begin{tabular}{lcc}
\hline \multicolumn{1}{c}{ Variabel } & $\mathbf{n}$ & $\mathbf{\%}$ \\
\hline Jenis Kelamin & & \\
\hline Laki-laki & 20 & 38,5 \\
\hline Perempuan & 32 & 61,5 \\
\hline Total & $\mathbf{5 2}$ & $\mathbf{1 0 0}$ \\
\hline Umur & & \\
\hline$>15$ Tahun & 46 & 88,5 \\
\hline$\leq 15$ Tahun & 6 & 11,5 \\
\hline Total & $\mathbf{5 2}$ & $\mathbf{1 0 0}$ \\
\hline Tingkat Pendidikan & \\
\hline Rendah & 28 & 53,8 \\
\hline Tinggi & 24 & 46,2 \\
\hline Total & $\mathbf{5 2}$ & $\mathbf{1 0 0}$ \\
\hline Tingkat Pengetahuan & \\
\hline Baik & 33 & 63,5 \\
\hline Kurang & 19 & 36,5 \\
\hline Total & $\mathbf{5 2}$ & $\mathbf{1 0 0}$ \\
\hline Personal Hygiene & \\
\hline Baik & 20 & 38,5 \\
\hline Kurang & 32 & 61,5 \\
\hline Total & $\mathbf{5 2}$ & $\mathbf{1 0 0}$ \\
\hline Status Gizi & & \\
\hline Tidak Normal & 15 & 28,8 \\
\hline Normal & 37 & 71,2 \\
\hline Total & $\mathbf{5 2}$ & $\mathbf{1 0 0}$ \\
\hline
\end{tabular}

Sumber : Data Responden Penelitian Puskesmas Tanjung Tahun 2018

Berdasarkan tabel 1, dari hasil analisis univariat didapatkan bahwa distribusi frekuensi jenis kelamin pada 52 responden adalah berjenis kelamin perempuan sebanyak 32 orang dengan prosentase sebesar $61,5 \%$.

Distribusi frekuensi untuk variabel umur pada 52 responden mayoritas berumur $>15$ tahun sebanyak 46 orang dengan prosentase sebesar $88,5 \%$.

Distribusi frekuensi untuk variabel tingkat pendidikan pada 52 responden adalah mempunyai tingkat pendidikan rendah sebanyak 28 orang dengan prosentase sebesar $53,8 \%$.

Distribusi frekuensi untuk variabel tingkat pengetahuan pada 52 responden adalah mempunyai tingkat pengetahuan baik sebanyak 33 orang dengan jumlah prosentase sebesar $63,5 \%$.

Distribusi frekuensi untuk variabel personal hygiene pada 52 responden adalah mempunyai personal hygiene kurang sebanyak 32 orang dengan jumlah prosentase sebesar $61,5 \%$.

Distribusi frekuensi untuk variabel status gizi pada 52 responden adalah mempunyai status gizi normal sebanyak 37 orang, dengan jumlah prosentase sebesar $71,2 \%$.

2. Hubungan Karakteristik Individu dengan Kejadian Penyakit Kusta.

Hasil analisis bivariat antara variabel karakteristik individu dengan kejadian penyakit kusta di Wilayah Kerja Puskesmas Tanjung Kabupaten Sampang tahun 2018 adalah sebagai berikut:

Tabel 2. Hubungan Karakteristik Individu dengan Kejadian Penyakit Kusta di Wilayah Kerja Puskesmas Tanjung Kabupaten Sampang Tahun 2018

\begin{tabular}{lccc}
\hline \multirow{2}{*}{ Variabel } & \multicolumn{2}{c}{ Kusta } & $\begin{array}{c}\text { P- } \\
\text { value }\end{array}$ \\
\cline { 2 - 3 } \multicolumn{2}{c}{ Jenis Kelamin } & - & \\
\hline Lk & 16 & 4 \\
& $(61,5 \%)$ & $(15,4 \%)$ & 0,001 \\
$\operatorname{Pr}$ & 10 & 22 & \\
& $(38,5 \%)$ & $(84,6 \%)$ & \\
\hline
\end{tabular}

\begin{tabular}{|c|c|c|c|}
\hline \multicolumn{4}{|l|}{ Umur } \\
\hline$>15 \mathrm{Th}$ & $\begin{array}{c}23 \\
(88,5 \%)\end{array}$ & $\begin{array}{c}23 \\
(88,5 \%)\end{array}$ & \\
\hline$\leq 15 \mathrm{Th}$ & $\begin{array}{c}3 \\
(11,5 \%)\end{array}$ & $\begin{array}{c}(11,5 \%) \\
(1,5 \%)\end{array}$ & 1,000 \\
\hline
\end{tabular}

Tingkat Pendidikan

\begin{tabular}{lccc}
\hline Rendah & 20 & 8 & \\
& $(76,9 \%)$ & $(30,8 \%)$ & 0 \\
\cline { 1 - 3 } & 0,001 \\
\cline { 1 - 3 } Tinggi & 6 & 18 & \\
\hline
\end{tabular}




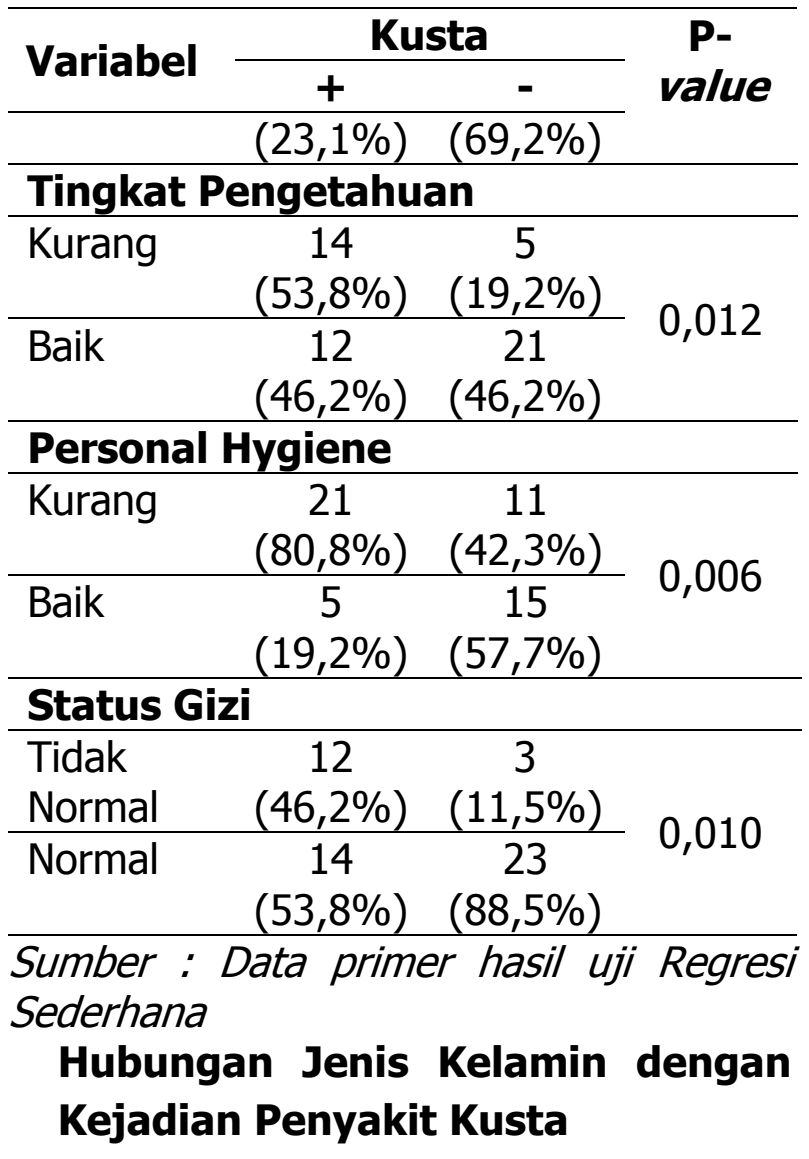

Berdasarkan tabel 2, dapat diketahui bahwa jumlah responden pada kelompok sakit, penyakit kusta lebih banyak diderita oleh jenis kelamin laki-laki dibandingkan perempuan yaitu sebanyak 16 orang $(61,5 \%)$. Sedangkan responden pada kelompok tidak sakit kusta lebih banyak berjenis kelamin perempuan dibanding laki-laki yaitu sebanyak 22 orang (84,6\%).

Hasil analisis bivariat antara jenis kelamin dengan kejadian penyakit kusta pada responden di wilayah kerja Puskesmas Tanjung menunjukkan bahwa jenis kelamin memiliki nilai pvalue sebesar 0,001 atau pvalue < a $(0,05)$, maka HO ditolak yang artinya ada hubungan antara jenis kelamin dengan kejadian penyakit kusta di wilayah kerja Puskesmas Tanjung.

Laki-laki cenderung lebih banyak yang menderita dibandingkan dengan perempuan dikarenakan laki-laki lebih banyak yang bekerja dibandingkan dengan perempuan.Hal ini sangat erat hubungannya dengan adat istiadat, dimana seorang laki-laki dituntut untuk bekerja dikarenakan harus memenuhi kebutuhan keluarganya. Tapi seiring berkembangnya zaman tidak menutup kemungkinan bahwa perempuan menjadi tulang punggung keluarganya (Manyullei S, Utama DA, Birawida AB, 2012).

Menurut Yuniarasari Y (2013), pekerjaan dapat menganalisis adanya kemungkinan risiko timbulnya penyakit. Jenis pekerjaan digolongkan menjadi pekerjaan ringan (tidak bekerja, pelajar, pegawai kantor) dan pekerjaan berat (pekerja bangunan, buruh, tukang batu, petani, nelayan). Berdasarkan hasil penelitian mayoritas responden yang bekerja adalah laki-laki dan memiliki pekerjaan yang masuk dalam golongan berat yaitu bekerja sebagai petani yaitu sebanyak 38 orang (73,1\%).

\section{Hubungan Umur dengan Kejadian Penyakit Kusta}

Berdasarkan tabel 2, dapat diketahui bahwa jumlah responden pada kelompok sakit, penyakit kusta banyak diderita oleh golongan umur > 15 tahun sebanyak 23 orang (88,5\%). Responden pada kelompok tidak sakit juga banyak pada kelompok umur $>15$ tahun sebanyak 23 orang (88,5\%).

Hasil analisis bivariat antara umur dengan kejadian penyakit kusta pada responden di wilayah kerja Puskesmas Tanjung menunjukkan bahwa umur memiliki nilai pvalue sebesar 1,000 atau pvalue $>$ a $(0,05)$, maka $\mathrm{HO}$ 
diterima yang artinya tidak ada hubungan antara umur dengan kejadian penyakit kusta di wilayah kerja Puskesmas Tanjung.

Kejadian penyakit sering dihubungkan dengan umur. Hubungan umur dengan imunitas mengakibatkan potensi terpapar faktor risiko penyakit dan aktivitas fisiologis tubuh. Jika dihubungkan dengan kusta, faktor umur sangat berperan dalam masa inkubasi karena masa inkubasi kusta yang cukup panjang sehingga kusta jarang ditemukan pada bayi.Insidens kusta meningkat jumlahnya sesuai umur dengan puncaknya pada umur 10-20 tahun (Depkes, 2004).

\section{Hubungan Tingkat Pendidikan dengan Kejadian Penyakit Kusta}

Berdasarkan tabel 2 dapat diketahui bahwa jumlah responden pada kelompok sakit, penyakit kusta banyak diderita oleh responden berpendidikan rendah daripada berpendidikan tinggi yaitu sebanyak 20 orang (76,9\%). Responden pada kelompok tidak sakit banyak berpendidikan tinggi dibandingkan berpendidikan rendah yaitu sebanyak 8 orang (30,8\%).

Hasil analisis bivariat antara tingkat pendidikan dengan kejadian penyakit kusta pada responden di wilayah kerja Puskesmas Tanjung menunjukkan bahwa tingkat pendidikan memiliki nilai pvalue sebesar 0,001 atau $\rho$ value < a $(0,05)$, maka $\mathrm{HO}$ ditolak yang artinya ada hubungan antara tingkat pendidikan dengan kejadian penyakit kusta di wilayah kerja Puskesmas Tanjung.
Menurut Wijayanti J (2017), pendidikan merupakan faktor yang sangat berpengaruh dalam penularan dan penyebaran kusta. Semakin rendah tingkat pendidikan seseorang semakin mudah terkena kusta, sedangkan semakin tinggi pendidikan seseorang semakin mudah memahami dan menerima berbagai macam informasi yang diberikan kepadanya.

\section{Hubungan Tingkat Pengetahuan dengan Kejadian Penyakit Kusta}

Berdasarkan tabel 2, dapat diketahui bahwa jumlah responden pada kelompok sakit, penyakit kusta banyak responden yang berpengetahuan kurang yaitu sebanyak 14 orang (53,8\%). Sedangkan responden pada kelompok tidak sakit, responden banyak berpengetahuan baik sebanyak 21 orang (80,8\%).

Hasil analisis bivariat antara tingkat pengetahuan dengan kejadian penyakit kusta pada responden di wilayah kerja Puskesmas Tanjung menunjukkan bahwa tingkat pengetahuan memiliki nilai pvalue sebesar 0,012 atau pvalue < a $(0,05)$, maka $\mathrm{HO}$ ditolak yang artinya ada hubungan antara tingkat pengetahuan dengan kejadian penyakit kusta di wilayah kerja Puskesmas Tanjung.

Pengetahuan berhubungan secara signifikan terhadap kejadian penyakit kusta, hal ini karena semakin tinggi atau semakin baik pengetahuan seseorang tentang penyakit kusta maka akan semakin baik pula sikap seseorang tersebut terhadap kejadian penyakit kusta. Minimnya pengetahuan tentang kusta menyebabkan penderita lambat berobat sehingga menimbulkan 
cacat dan berpotensi menularkan kuman. Masa inkubasi yang panjang, bisa lebih dari 10 tahun (sepuluh) tahun dan tanpa rasa sakit menyebabkan penderita kerap tidak menyadari bahwa dirinya terkena kusta, sehingga hal tersebut berdampak pada kasus kusta yang setiap tahunnya meningkat (Ramadhani DS dkk, 2013).

\section{Hubungan Personal Hygiene dengan Kejadian Penyakit Kusta}

Berdasarkan tabel 2, dapat diketahui bahwa jumlah responden pada kelompok sakit, penyakit kusta banyak diderita oleh responden yang memiliki personal hygiene kurang yaitu sebanyak 21 orang $(80,8 \%)$. Sedangkan pada kelompok tidak sakit, responden banyak memiliki personal hygiene kurang yaitu sebanyak 11 orang (42,3\%).

Hasil analisis bivariat antara personal hygiene dengan kejadian penyakit kusta pada responden di wilayah kerja Puskesmas Tanjung menunjukkan bahwa personal hygiene memiliki nilai $\rho$ value sebesar 0,006 atau $p$ value < a $(0,05)$, maka $\mathrm{HO}$ ditolak yang artinya ada hubungan antara personal hygiene dengan kejadian penyakit kusta di wilayah kerja Puskesmas Tanjung.

Personal hygiene dikarenakan perilaku hidup bersih dan sehat terutama kebersihan seseorang pada umumnya kurang mendapat perhatian diri sendiri. Sehingga dapat menyebabkan timbulnya penyakit kusta. Penyakit kusta dapat menyerang semua orang. Kuman tumbuh dan bersarang dikulit jika dibiarkan dapat merajalela ke bagian tubuh mana saja.Bagian tubuh anggota gerak rusak, karena sarafnya mati dan hidung jadi keropos. Kulit tidak dapat merasakan apa-apa dan terluka tanpa disadari (Irianto, 2005).

\section{Hubungan Status Gizi dengan Kejadian Penyakit Kusta}

Berdasarkan tabel 2, dapat diketahui bahwa responden pada kelompok sakit, penyakit kusta berstatus gizi tidak normal lebih sedikit dibandingkan berstatus gizi normal yaitu sebanyak 12 orang (46,2\%). Responden pada kelompok tidak sakit, penyakit kusta berstatus gizi tidak normal juga lebih banyak dibandingkan berstatus gizi normal yaitu sebanyak 3 orang $(11,5 \%)$.

Hasil analisis bivariat antara status gizi dengan kejadian penyakit kusta pada responden di wilayah kerja Puskesmas Tanjung menunjukkan bahwa personal hygiene memiliki nilai pvalue sebesar 0,010 atau pvalue < a $(0,05)$, maka HO ditolak yang artinya ada hubungan antara status gizi dengan kejadian penyakit kusta di wilayah kerja Puskesmas Tanjung.

Status gizi pada pasien kusta memiliki pengaruh nyata terhadap daya tahan tubuhnya.Hal ini disebabkan status gizi yang baik adalah proteksi yang baik untuk melawan virus patogen dalam tubuh. Sistem imunologi yang didukung sepenuhnya oleh protein tubuh, akan memberikan pertahanan maksimal dan mengurangi efek kerusakan jaringan akibat infeksi virus dan bakteri oleh tubuh. Interaksi antara infeksi termasuk penyakit kusta dan gizi di dalam tubuh seseorang 
dikemukakan sebagai suatu peristiwa sinergistik, selama terjadinya infeksi, status gizi akan menurun dan orang tersebut menjadi kurang resisten terhadap infeksi. Respon imun menjadi kurang efektif dan kuat ketika seseorang mengalami gizi kurang (Apriani, Rismayanti, Wahidudin, 2013).

3. Analisis Multivariat

Variabel yang dimasukkan dalam analisis multivariat adalah variabel independen yang pada uji bivariat memiliki nilai $p<0,25$ dan yang memiliki hubungan secara substansi dengan kejadian penyakit kusta. Hasil analisis multivariat tersebut selengkapnya dapat dilihat pada Tabal V.14 berikut ini:

Tabel 3. Hasil Analisis Multivariat Karakteristik Individu Terhadap Kejadian Penyakit Kusta

\begin{tabular}{|c|c|c|c|}
\hline Variabel & OR & $\begin{array}{c}95 \% \\
\text { CI }\end{array}$ & $\begin{array}{c}p- \\
\text { value }\end{array}$ \\
\hline $\begin{array}{l}\text { Jenis } \\
\text { Kelamin }\end{array}$ & 0,050 & $\begin{array}{c}0,006- \\
0,406\end{array}$ & 0,005 \\
\hline T.Pend & & $\begin{array}{l}0,019- \\
0,605\end{array}$ & 0,012 \\
\hline T.Peng & & $\begin{array}{l}0,065- \\
2,723\end{array}$ & 0,363 \\
\hline $\begin{array}{l}\text { Personal } \\
\text { Hygiene }\end{array}$ & & $\begin{array}{l}0,014- \\
0,892\end{array}$ & 0,039 \\
\hline $\begin{array}{l}\text { Status } \\
\text { Gizi }\end{array}$ & & $\begin{array}{l}0,025- \\
1,742 \\
\end{array}$ & 0,148 \\
\hline
\end{tabular}

Sumber : Data primer hasil uji Regresi Ganda pada Analisis Multivariat

Dari semua variabel dianalisis secara bertahap atau dengan metode Enter, Didapatkan bahwa variabel : 1) jenis kelamin, 2) tingkat pendidikan dan 3) personal hygiene mempunyai pengaruh yang bermakna dalam terjadinya penyakit kusta di Wilayah
Kerja Puskesmas Tanjung ( $\rho$-value < 0.05).

Faktor risiko pertama yaitu jenis kelamin dengan pvalue sebesar 0,005 dan hasilnya menerangkan bahwa jenis kelamin laki-laki mempunyai risiko penyakit kusta sebesar 0,050 kali dibandingkan jenis kelamin perempuan.

Faktor kedua yatu tingkat pendidikan mempunyai nilai pvalue sebesar 0,012 dan hasilnya menerangkan bahwa tingkat pendidikan rendah mempunyai risiko penyakit kusta sebesar 0,106 kali dibandingkan tingkat pendidikan tinggi. Selanjutnya faktor ketiga yaitu personal hygiene mempunyai nilai pvalue sebesar 0,039 dan hasilnya menerangkan bahwa personal hygiene yang kurang mempunyai risiko penyakit kusta 0,110 kali dibandingkan dengan personal hygiene baik.

Mengingat bahwa jenis kelamin laki-laki banyak terserang penyakit kusta dibandingkan dengan perempuan. Relatif rendahnya kusta pada perempuan kemungkinan karena faktor lingkungan atau faktor biologi. Laki-laki cenderung lebih banyak yang bekerja dibandingkan dengan perempuan dikarenakan laki-laki lebih banyak yang bekerja dibandingkan dengan perempuan. Selain pekerjaan, laki-laki kurang memperhatikan kebersihan dirinya dibandingkan dengan perempuan. Hal tersebut diperparah jika memiliki tingkat pendidikan yang rendah, karena pendidikan merupakan faktor yang sangat berpengaruh dalam penularan dan penyebaran kusta. Sedangkan semakin tinggi pendidikan seseorang 
semakin mudah memahami dan menerima berbagai informasi yang diberikan kepadanya. Risiko tersebut akan meningkat jika memiliki personal hygiene kurang.

\section{Kesimpulan}

1. Karakteristik individu pada 52 responden di Wilayah Kerja Puskesmas berdasarkan jenis kelamin yaitu $61.5 \%$ berjenis kelamin perempuan, berdasarkan umur yaitu $88,5 \%$ berumur > 15 tahun, berdasarkan tingkat pendidikan yaitu $53,8 \%$ berpendidikan rendah, berdasarkan tingkat pengetahuan yaitu $63,5 \%$ berpengetahuan baik, berdasarkan personal hygiene yaitu $61,5 \%$ memiliki personal hygiene kurang, berdasarkan status gizi yaitu $71,2 \%$ berstatus gizi normal.

2. Ada hubungan antara jenis kelamin dengan kejadian penyakit kusta di Wilayah Kerja Puskesmas Tanjung.

3. Tidak ada hubungan antara umur dengan kejadian penyakit kusta di Wilayah Kerja Puskesmas Tanjung.

4. Ada hubungan antara tingkat pendidikan dengan kejadian penyakit kusta di Wilayah Kerja Puskesmas Tanjung.

5. Ada hubungan antara tingkat pengetahuan dengan kejadian penyakit kusta di Wilayah Kerja Puskesmas Tanjung.

6. Ada hubungan antara personal hygiene dengan kejadian penyakit kusta di Wilayah Kerja Puskesmas Tanjung.

7. Ada hubungan antara status gizi dengan kejadian penyakit kusta di Wilayah Kerja Puskesmas Tanjung
8. Secara multivariat 3 faktor yang berpengaruh adalah variabel jenis kelamin, tingkat pendidikan, dan personal hygiene terhadap kejadian penyakit kusta di Wilayah Kerja Puskesmas Tanjung.

\section{Saran}

1. Bagi instansi yang terkait (Dinas Kesehatan dan Puskesmas)

a. Dinas Kesehatan

1) Menganalisis atau membuat prioritas untuk meningkatkan penyuluhan kesehatan.

2) Bekerjasama dengan lintas program dan lintas sektor dalam kegiatan penyuluhan kesehatan.

b. Puskesmas

1) Perlu mengoptimalkan program pengendalian penyakit kusta diantaranya dengan melakukan kerjasama dengan kader untuk melakukan penyuluhan secara langsung maupun tidak langsung melalui media cetak maupun elektronik tentang pengertian, gejala, cara penularan, pengobatan maupun pencegahan penyakit kusta terhadap masyarakat bukan hanya penderita dan keluarga saja melainkan kepada tokoh agama, tokoh masyarakat dan guru yang

2) dianggap mempunyai pengaruh terhadap masyarakat.

3) Memotivasi atau memberikan informasi tentang manfaat membiasakan Hidup Bersih dan Sehat (PHBS) untuk mencegah terjadinya gangguan kesehatan. 
2. Bagi Masyarakat

a. Sebaiknya mengikuti penyuluhan tentang penyakit kusta dan dapat berperan serta dalam upaya pencegahan dan penanggulangan kusta.

b. Sebaiknya laki-laki lebih meningkatkan personal hygiene untuk mencegah terjadinya gangguan kesehatan.

3. Bagi Peneliti Lain

Perlu adanya penelitian lebih lanjut terkait faktor lain yang tidak diteliti dalam penelitian ini yaitu riwayat kontak pada anggota keluarga penderita kusta.

\section{DAFTAR PUSTAKA}

Apriani DW, Rismayanti, Wahiduddin., 2013. Faktor Risiko Kejadian Penyakit Kusta di Kota Makassar. Fakultas Kesehatan Masyarakat Universitas Hasanuddin

Departemen Kesehatan RI., 2004. Buku Pedoman Nasional Pemberantasan Penyakit Kusta. Jakarta: Depkes RI

Irianto, K., 2005. Mikrobiologi Menguak Dunia Mikroorganisme Jilid 1\&2. Bandung: Yrama Widya

Manyullei, S dan Utama, DA dan Birawida $A B$, 2012. Gambaran Faktor Yang Berhubungan Dengan Penderita Kusta di Kecamatan Tamale Kota Makassar. Indonesian Journal of Public Health. Vol. 1 No.1:10-7
Namira, N., 2014. Faktor yang Berhubungan Dengan Kejadian Kusta di Wilayah Kerja Puskesmas Kapita Kabupaten Jeneponto. Skripsi. Universitas Islam Alauddin Makassar

Rahfiludin, M Zen dan Apoina $\mathrm{K}$ dan Distrika P., 2005. Hubungan Tingkat Konsumsi Energi dan Protein Dengan Kadar Immunoglobulin (IgM) ANTI Phenolic Glycolipid-1 (PGL-1) Narakontak Serumah Penderita Kusta di Kota Semarang. Vol 2 No. 2

Ramadhani D.S, dkk., 2013. Determinan Kejadian Penyakit Kusta Di Wilayah Keja Puskesmas Kecamatan Limo Tahun 2013

Widoyono., 2011. Penyakit Tropis: Epidemiologi, Penularan, Pencegahan, dan Pemberantasannya Edisi Kedua. Jakarta: Erlangga

Wijayanti, J., 2017. Gambaran Faktor Host dan Lingkungan Fisik Rumah Pada Penderita Kusta di Kota Tangerang Selatan Tahun 2017. Skripsi. Universitas Islam Negeri Syarif Hidayatullah

Yuniarasari, Y., 2013. Faktor-Faktor Yang Berhubungan Dengan Kejadia Kusta (Studi Kasus di Wilayah Kerja Puskesmas Gunem dan Puskesmas Sarang Kabupaten Rembang Tahun 2011). Skripsi. Universitas Negeri Semarang 